\title{
Water Extracts From Trees Negatively Affect Oviposition Behavior and Fitness of Southern House Mosquito, Culex Quinquefasciatus Say (Diptera: Culicidae): A Simple, Easily Adoptable and Cost-Effective Approach to Control Mosquitoes
}

Muhammad Khan

bzu

Rizwan shah ( $\nabla$ rizwanmustafa20@gmail.com )

Bahauddin Zakariya University https://orcid.org/0000-0002-7168-5700

\section{Sarfraz Ali Shad}

BZU: Bahauddin Zakariya University

\section{Shahid Majeed}

BZU: Bahauddin Zakariya University

Shahbaz Ahmad

BZU: Bahauddin Zakariya University

Muhammad Binyameen

BZU: Bahauddin Zakariya University

\section{Research}

Keywords: Botanical Extract, Mosquito Management, Oviposition Behaviour

Posted Date: January 18th, 2021

DOI: https://doi.org/10.21203/rs.3.rs-143809/v1

License: (c) (i) This work is licensed under a Creative Commons Attribution 4.0 International License.

Read Full License 


\section{Abstract}

Background: The Culex quinquefasciatus Say is an important vector of many diseases of public health and veterinary importance. Environmental pollution, resistance development and health hazards associated with the use of synthetic insecticides have led to explore eco-friendly and cost effective management methods for mosquitoes.

Methods: In our study, simple water extracts from leaves and bark of three tree species; Eucalyptus camaldulensis, Azadirachta indica (Neem), and Moringa oleifera, were tested to explore their potential negative effects on the oviposition behavior and fitness of $C x$. quinquefasciatus.

Results: Oviposition bioassays showed a significant delay in onset of $1^{\text {st }}$ oviposition in the all treatments as compred to control. Number of egg rafts and fecundity were significantly lower in all treatments compared to control. Larval emergence was significantly less in the all treatments as compared with the control except Moringa bark. Highest pupation was observed in control as compared to all other treatments. Importantly, no adult emerged in Eucalyptus leaf, bark and in Neem bark extracts. In case of toxicity bioassays, median lethal time $\left(\mathrm{LT}_{50}\right)$ was lower at higher concentrations and higher at lower concentrations. At highest tested concentration of every botanical extract, $\mathrm{LT}_{50}$ was highly age dependent that is higher for elder larvae and vice versa.

Conclusions: Therefore, it could be concluded that simple water extrcats, made locally, from trees may have a great potential to be incorporated in the mosquito control programs.

\section{Background}

Southern house mosquito, Culex quinquefasciatus Say, is a vector of many zoonotic diseases that affect humans and wild and domestic animals, such as avian malaria, Western equine encephalitis, lymphatic filariasis, St. Louis encephalitis, West Nile fever and Zika virus (Guedes et al. 2017; Simonsen and Mwakitalu 2013). Mortality rate due to vector-borne filariasis is low but a high morbidity rate is a social stigma. According to estimates, about 120 million people in 81 countries are currently infected, and 1.34 billion people who live in areas endemic to filariasis are at risk of infection (Sangshetti et al. 2017). In Pakistan, population of $C x$. quinquefasciatus develops rapidly during rainy season and becomes a sever biting nuisance leading to restless nights (Tahir et al. 2009). Although, the ornithophilic behavior of $C x$. quinquefasciatus is well reported, but the preference changes to mammals in the absence of primary host, which leads to significant impact (Kilpatrick et al. 2006).

Application of synthetic insecticides as larvicides, insecticide-treated nets and indoor residual spraying (IRS) are the principal mosquito management measures adapted worldwide (Okumu et al. 2011). So far, chemical insecticides are the most effective control measures against mosquitoes, however, resistance against these chemical insecticides has recently been reported in many species of mosquitoes, which is resulting in repeated epidemic (Guessan et al. 2007; Van Bortel et al. 2008). Moreover, residual effects of synthetic insecticides are imposing serious threat to humans, animals, plants health and environment 
(References?). These major concerns have diverted the attention of researchers towards natural chemicals, such as plant extracts or oils, which are cost effective, safe, target specific and easily biodegradable in the environment (Borah et al. 2010; Hafeez et al. 2011).

It has been shown by several studies that plant extracts or their non-volatile and volatile constituents have a great potential to be used as insecticides and insect repellents, respectively (Cetin et al. 2004; Lucantoni et al. 2006). Previously, different parts of medicinal plants such as leaves, seeds, peel, and succulent branches have shown great mosquitocidal properties (Ashfaq and Ashfaq 2012; Shaalan et al. 2005). In the current study, we have observed the female oviposition behavior and development period from hatching till adult emergence. This is the first study where trees extracts have been tested while previously mostly small plant extracts have been tested on mosquitoes. Moreover, mosquitoes might be more familiar with small vegetation like grasses and shrubs to hide during the day, while large trees like Eucalyptu, Neem and Moringa are something new and may induce behaviroal and physiological changes more effectively than other plants. For this purpose, we have used leaves and bark extracts of three tree species; Moringa oleifera, Azadirachta indica and Eucalyptus camaldulensis to explore their potential negative effects on the oviposition behavior and fitness as well as toxicity on immature stages of $C X$. quinquefasciatus.

\section{Methods}

\section{Insects}

Pupae as well as larvae of $C x$. quinquefasciatus were collected from the sewage line of student hostel area of Bahauddin Zakariya University, Multan ( $\left.30^{\circ} 5^{\prime} 11 \mathrm{~N}, 71^{\circ} 39^{\prime} 15 \mathrm{E}\right)$, Punjab, Pakistan. The pupae and larvae were kept in plastic containers $(2 \mathrm{~L})$, containing the same sewerage water $(1 \mathrm{~L})$ and covered at open end with a muslin cloth in laboratory till emergence of adults. After emergence, male and female adults were kept together in the Plexiglas cages $(1 \times 1 \times 1 \mathrm{ft})$ for mating purpose and provided with $10 \%$ sugar solution for feeding provided on an ad libitum hydrated cotton pad. After 3-4 days, only females were given a pigeon with exposed keel for a period of $12 \mathrm{~h}$ (overnight) for blood feeding in dark conditions. After blood-feeding, blood-fed females were kept for next $48 \mathrm{~h}$ post-blood feeding prior to use in further experiments. All the experiments were conducted under standard laboratory conditions of temperature at $27 \pm 2{ }^{\circ} \mathrm{C}$, light: dark (12: $12 \mathrm{~h}$ ) photoperiod, and relative humidity $70 \pm 5 \%$ (Shah et al. 2017).

\section{Preparation of plant water extracts}

Water based plant extracts were prepared by following the methods used by Wakil et al. (2014) and Arunpandiyan (2011) with some modifications. Comprehensively, $500 \mathrm{~g}$ of fresh leaves as well as stembark of three different plant species (Moringa oleifera, Azadirachta indica and Eucalyptus camaldulensis) were collected separately in polythene bags. After collection, bark and leaves were grinded separately in mortar and pestle as well as in electric grinder (Black \& Decker Company, New Britain, Connecticut, United 
States) by adding $500-800 \mathrm{~mL}$ of distilled water to make a uniform paste. Distilled water was added in the paste to make an amount of $2 \mathrm{~L}$ containing $500 \mathrm{gm}$ of bark or leaves. Liquid mixtures of each botanical were poured in separate sterilized steel containers $(5 \mathrm{~L})$. These mixtures were stirred with a dried wooden stick continuously at an interval of 10-15 min for next three hours. After $3 \mathrm{~h}$, mixtures were further extracted by using fine muslin cloth. After filtering the liquid, the remaining bark or leaf matter was pressed as much as possible to take out water from it. Furthermore, a standard solution $(1000 \mathrm{~mL})$ of $10 \%(\mathrm{w} / \mathrm{v})$ for each type of extract was prepared by taking the required amount of filtrate and adding distilled water to prepare the solution of desired molarity. All the solutions were kept and maintained at 4 ${ }^{\circ} \mathrm{C}$ in the refrigerator.

\section{Oviposition bioassay}

For oviposition bioassays, $10 \mathrm{~mL}$ of $10 \%$ extract was added into a plastic cup (120 mL) containing $90 \mathrm{~mL}$ distilled water to make $1 \%(\mathrm{w} / \mathrm{v})$ solution (i.e. $1 \mathrm{gm}$ leaf weight in $99 \mathrm{~mL}$ water). Plastic cups containing $100 \mathrm{~mL}$ of different extracts (1\%) i.e. Neem leaf (Neem L), Neem bark (Neem B), Eucalyptus leaf (Eucalyptus L), Eucalyptus bark (Eucalyptus B), Moringa leaf (Moringa L), and Moringa bark (Moringa B) were placed singly in adult cages as oviposition substrates and 10 blood-fed females were released in each cage including control containing only distilled water and 5 replications were completed for each and every extract type and control. Oviposition was observed on daily basis till death of last female in each treatment. Ovipositional substrates (botanical solution or distilled water in case of control) were replaced with the fresh ones at an interval of $48 \mathrm{~h}$ to avoid any fungal development. Number of egg rafts and number of eggs in each egg raft were counted (under a compound microscope having a magnification of $4 \mathrm{X}$ ) on daily basis throughout the life span of females. Female longevity was also noted by observing the female mortality on daily basis till the last female died.

\section{Larval development}

Effects of tested plant extracts on the larval development of $C x$. quinquefasciatus were also examined. An egg raft was placed in plastic cup containing $100 \mathrm{~mL}$ of $1 \%$ plant extract or the only distilled water (control). Larval emergence, larval mortality, pupae formation, and adult emergence were observed on daily basis $(24 \mathrm{~h})$ till all the larvae became pupae and adults. An egg raft was considered as a replicate and each treatment was replicated five times. Rearing mediums (extract or distilled water) were refreshed after every $48 \mathrm{~h}$.

\section{Larvicide bioassays}

The larval toxicity of tested botanicals (mentioned above) was evaluated against the $24 \mathrm{~h}, 48 \mathrm{~h}$ and $72 \mathrm{~h}$ old larvae of $C x$. quinquefasciatus following the methodology described by World Health Organization (1996) with some modifications. Four concentrations of each botanical were prepared ranging from 100 
ppm to $100,000 \mathrm{ppm}$. Each concentration was replicated five times. Ten (for each age group) larvae were used in each replicate, i.e., 50 larvae per concentration and 250 larvae in one bioassay including control. The control was consisted of only water. The data was recorded at $24 \mathrm{~h}, 48 \mathrm{~h}, 72 \mathrm{~h}$ and $96 \mathrm{~h}$ intervals. All those larvae which were unable to move were considered dead.

\section{Data analysis}

The Shapiro-Wilk test was applied to test the normality of the data and $P$-values of less than 0.05 were considered as significant (data set was taken as non-normal). Therefore, non-parametric test, MannWhitney U-test was used for pairwise comparison of different parameters of each treatment including delay in $1^{\text {st }}$ oviposition, female fecundity, larval emergence, larval development, pupation, adult emergence, larval survival, adult survival and longevity compared to that of control. For significance level, a was set at $5 \%$ and $P$-values of less than 0.05 were considered as significant. All the data were analyzed by using IBM SPSS Statistics $v 21$. The concentration response data was analyzed by probit analysis (Finney 1971 ) to determine the median lethal time $\left(L T_{50}\right)$ values, their $95 \%$ confidence intervals $(\mathrm{Cl})$, slope \pm standard error (SE) and chi square $\left(\chi^{2}\right)$. $\mathrm{LT}_{50}$ values were considered significantly different when their 95\% Cl did not overlap (Litchfield and Wilcoxon 1949; Robertson and Preisler 1992). Pearson correlation was applied to determine the coefficient of correlation and significance of correlation $(P<0.05)$ between the $L T_{50}$ values and different age groups of exposed larvae at highest tested concentration of different botanicals.

\section{Results}

\section{Delay in onset of $1^{\text {st }}$ oviposition}

The $1^{\text {st }}$ oviposition started earlier in control than all other treatments. The highly significant delay in oviposition was observed in Eucalyptus leaf $(U=9, P=0.046)$ as compared to the control (Figure 1). Similarly, the $1^{\text {st }}$ oviposition was delayed with significant effect in Eucalyptus bark $(U=9, P=0.046)$, Neem leaf $(U=9, P=0.043)$, Neem bark $(U=9, P=0.046)$, Moringa leaf $(U=9, P=0.043)$ and Moringa bark $(U=9$, $P=0.046$ ) as compared to control (Figure 1).

\section{Female fecundity}

\section{Number of egg rafts}

Numbers of egg rafts laid per female in Neem leaf $(U=1, P=0.11)$, Moringa leaf $(U=1.5, P=0.18)$ and Moringa bark $(U=1, P=0.08)$ did not differ significantly than that of control (Figure 2). Females exposed to 
botanical extracts of Eucalyptus bark ( $U=0.0, P=0.05)$, Eucalyptus leaf $(\mathrm{U}=0, P=0.05)$ and Neem bark $(\mathrm{U}=0$, $P=0.05)$ laid similar number of egg rafts significantly lower as compared with that of control.

\section{Number of eggs/female}

Number of eggs laid by a female were significantly lower in Eucalyptus leaf ( $U=0.0, P=0.05)$, Eucalyptus bark $(U=0.0, P=0.05)$, Neem leaf $(U=0.0, P=0.05)$, Neem bark $(U=0, P=0.05)$, Moringa leaf $(U=0.0, P=0.05)$ and Moringa bark $(U=0.0, P=0.05)$ compared to control (Figure 3$)$.

\section{Larval emergence}

The larval emergence was maximum in the control and was significantly reduced in Neem leaf $(\mathrm{U}=0.0$, $P=0.05)$, Eucalyptus bark ( $U=0, P=0.05)$, Eucalyptus leaf $(U=0, P=0.05)$ and in Moringa leaf $(U=0, P=0.05)$. However, Neem bark $(U=0, P=0.05)$ and Moringa bark $(U=5, P=0.83)$ did not show any negative effect on larval emergence as compared to control (Figure 4).

\section{Pupation}

Highest pupation (\%) in control was observed while no pupae were formed in Eucalyptus leaf $(\mathrm{U}=0.0$, $P=0.04)$ and Eucalyptus bark ( $\mathrm{U}=0.0, P=0.04)$. Pupation (\%) was significantly lower in Neem leaf $(\mathrm{U}=0.0$, $P=0.04)$ and Neem bark $(U=0.0, P=0.05)$ as compared with control. A relatively higher proportion of pupae were formed in Moringa leaf $(U=0.0, P=0.05)$ and Moringa bark $(U=0.0, P=0.05)$ but significantly lower as compared to control (Figure 5).

\section{Adult emergence}

As no pupae were formed in Eucalyptus leaves and bark, there was no adult emergence in Eucalyptus leaf $(\mathrm{U}=0.0, P=0.05)$ and bark $(\mathrm{U}=0.0, P=0.04)$. Moreover, no adults were emerged in Neem bark $(\mathrm{U}=0.0$, $P=0.04)$ (Figure 6). Adult emergence was significantly lower in Neem leaf extract $(U=0.0, P=0.046)$ and Moringa leaf $(U=0.0, P=0.05)$ as compared to the control. However, Moringa bark $(U=2.0, P=0.28)$ did not reduce adult emergence of $C x$. quinquefasciatus as compared with control (Figure 6).

\section{Lethal time $\left(\mathrm{LT}_{50}\right)$ of botanical extracts to different ages of larvae}

In case of $24 \mathrm{~h}$ old larvae, the $\mathrm{LT}_{50}$ values of the Neem leaf (100,000 PPM), Neem Bark (100,000 PPM), Moringa leaf (100,000 PPM), Eucalyptus leaf (100,000 PPM) were similar to each other based on the overlapping $95 \% \mathrm{Cl}$ and were the least time taking among all tested concentrations to kill the $50 \%$ 
population of the exposed larvae (Table 1). While, Neem leaf (100 PPM), Moringa leaf (100 PPM) and Eucalyptus leaf (100 PPM) were longest time taking concentrations among all the tested concentrations against $24 \mathrm{~h}$ old larvae to kill the $50 \%$ population of the exposed larvae. Neem bark (100 PPM) and Moringa bark (100 PPM) did not kill any of the exposed population.

When 48h larvae were exposed to different botanical concentrations, Neem leaf (100,000 PPM), Neem bark (100,000 PPM), Eucalyptus Leaf (100,000 PPM) and Eucalyptus bark were the concentrations having similar $\mathrm{LT}_{50}$ based on overlapping $95 \% \mathrm{Cl}$ and the shortest time taking (Table 2). Moreover, the neem leaf (100 PPM) was the longest time taking concentration among all tested concentrations to kill fifty percent of the population. However, Moringa bark (100 PPM) did not kill any larvae exposed to it.

In case of $72 \mathrm{~h}$ old larvae, Neem leaf (100,000 PPM), Neem bark (100,000 PPM), Moringa Bark (100,000 PPM), Eucalyptus Leaf (100,000 PPM) and Eucalyptus bark (100,000 PPM) were similar based on overlapping $95 \% \mathrm{Cl}$ and lowest time taking concentrations among all the tested concentrations (Table 3 ). No mortality was observed at 100 PPM of all the tested botanicals and 1000 PPM of the Neem leaf, Moringa leaf, Moringa bark and Eucalyptus Bark.

At highest tested concentration of every botanical, $L T_{50}$ was highly age dependent that is higher for elder larvae and vice versa (Table 4). Our results showed a strong positive but non-significant correlation between the different age groups and $\mathrm{LT}_{50}$ values of the highest tested concentrations of the tested botanicals.

\section{Discussion}

Application of synthetic pesticides for the control of insect vectors is questioned due to resistance, environmental pollution and public health problems (Rose 2001). Whereas, various studies suggested botanical extracts are an effective tool for the control of insect pests (Mohan et al. 2006; Rahuman et al. 2008; Shahi et al. 2010). Demand for exploration of the eco-friendly control tactics against mosquitos is on rise day by day (Benelli et al. 2016). Some phytochemicals interfere with growth and development either with reproduction or acting as olfactory stimulus in form of repellent or attractant, while some act as common toxicants against larval and adult stages of mosquitoes (Shaalan et al. 2005).

Our results suggest that onset of $1^{\text {st }}$ oviposition was delayed as compared with control, when females were exposed to each of tested botanical extracts. Previously, Rajkumar and Jebanesan (2009) have reported negative impact of Cassia obtusifolia on oviposition behavior of the mosquitoes. Mehra and Hiradhar (2002) reported that Cuscuta hyaline crude extract showed good oviposition deterrence against Cx. quinquefasciatus females. Moreover, Coria et al. (2008) also reported that Melia azidarach leaf extracts has deterrent effects on oviposition of Ae. aegypti. Our results are also in line with that of Govindarajan et al. (2011b) who has shown that the leaf extracts of Caesalpinia pulcherrima and Ervatamia coronariaand have activities (larvicidal and ovicidal) against Anopheles stephensi, Ae. aegypti, and $C x$. quinquefasciatus. Similar findings has been reported by Elango et al. (2009) that indigenous 
plant extracts such as Aegle marmelos, Andrographis lineate, Andrographis paniculata, Cocculus hirsutus, Eclipta prostrata, and Tagetes erecta have oviposition-deterrent, ovicidal, and repellent activity against An. subpictus. As oviposition was significantly delayed in exposed females in all treatments, oviposition deterrent activity of plant extracts might induce physiological changes leading to behavioral avoidance in female adult mosquitoes. It might also be due to volatile chemicals released from respective plant water extracts, which were added in their oviposition substrates. Tawatsin et al. (2006) has also reported that the relatively high oviposition deterrent activity was induced by essential oils of Curcuma longa, Zingiber officinale, Vitex trifolia, Melaleuca cajuputi, Manglietia garrettii, and Houttuynia cordata. The delay in oviposition leads to lower female fecundity and thus it is obvious that with vast biodiversity, many bioactive compounds could be isolated and utilized for mosquito control especially $C X$.

quinquefasciatus. Moreover, adding simple water extracts of potential botanicals in the standing waters in ditches, ponds or in sewerage lines, which are the main breeding sites of $C x$. quinquefasciatus, may help to deter gravid females or delaying the oviposition leading to less female fecundity and ultimately less population of $C x$. quinquefasciatus.

Larval emergence was significantly lower in Neem leaf, Eucalyptus leaf, Eucalyptus bark and Neem bark. Prathibha et al. (2014) found that the ethyl acetate extracts of $S$. mauritiana have marked effect results in zero hatchability at $100 \mathrm{ppm}$ against $A n$. stephensi, Ae. aegypti, and $C x$. quinquefasciatus. Previously, $M$. oleifera seed water extract has been reported to exhibit $80 \%, 41.3 \%$ and $9.33 \%$ larval mortality at $5 \%, 2.5 \%$ and $1 \%$ concentrations on larvae of Anopheles gambiae (NJOM et al. 2011). At higher concentration (5\% and $2.5 \%$, no larvae reached to pupal stage but at lower concentration even few adults were emerged. Similarly,Tandon and Sirohi (2010) reported that $A$. indica aqueous crude leaf extract caused $70-99 \%$ larval mortality followed by Gymnema sylvestre $44-89 \%$, Nerium indicum $41-74 \%$ and Datura metel 19$54 \%$ mortality of larvae. An inverse impact of botanical extracts on hatchability of eggs was observed against $C x$. quinquefasciatus (Govindarajan et al. 2011a). Hence, it can be concluded that unprocessed water extracts of tested plant have more potential to suppress the life table of target insects due to presence of more diverse compounds (Naumann and Isman 1995).

In the present study, no pupation occurred in Eucalyptus leaf and in Eucalyptus bark, while very few pupae were formed in Neem leaf and Neem bark. These results are similar to NJOM et al. (2011) where higher concentration of Moringa seed extracts did not allow any pupation. Previously, hexane based leaves extract of Eucalyptus has shown potential to suppress the pupal formation in from larvae of different exposed mosquito species including Cx. quinquefasciatus (Singh et al. 2007). This also indicates that plant extracts can kill the larvae as well as pupae of mosquitoes.

In the present study, no adult emergence in Eucalyptus leaf, Eucalyptus bark and Neem bark while was highly significantly lower in Neem leaf. Elimam et al. (2009) reported that aqueous extracts from Ricinus communis inhibit adult emergence and also showed larvicidal as well as oviposition deterrent effect against $C x$. quinquefasciatus and $A n$. arabiensis.

\section{Conclusions}


The water based botanical extracts of bark and leaves of the all tested species showed a variable range of larvicidal activity against the larvae of the $C x$. quinquefasciatus but have potential to be used as the traditional control agents. Among the tested botanicals, mortality of the larvae was highly dose dependent. Highest mortality at higher doses and lowest or no mortality was observed at lowest doses of the tested botanicals in our study. Previously, Govindarajan et al. (2011b) reported the similar dose dependent response of the $C x$. quinquefasciatus to botanicals. Cetin et al. (2006) reported a similar dose dependent response of $C x$. pipens exposed to plant extracts. Therefore, application, keeping in view the dose response of the target species, of these easily made botanical extracts shall be considered at least at small scale level, e.g., homes and poultry farms.

\section{Declarations}

- Ethics approval and consent to participate: No human beings were subject of experiments; therefore, no consent to participate was required.

- Consent for publication: No human beings were subject of experiments; therefore, no consent to Publish was required

- Availability of data and material: Data will be available on demand

- Author Contribution: MK and RMS performed the experiment, SA, SM, SA and MB designed the experiment, provided materials and guidelines to perform the experiments. MK and RMS wrote the MS. SA, SM, SA and MB critically reviewed and finalized it.

- Funding: The authors did not receive support from any organization for the submitted work

- Competing interests: The authors hereby declared no competing interests

- Acknowledgements: All the authors are cordially thankful to laboratory staff in helping to perform labor work during experimentation.

\section{References}

1. Arunpandiyan G (2011) Toxicity of aqueous crude neem leaf extract against Culex Int J Pharm Biomed Sci 2(1):1-3

2. Ashfaq M, Ashfaq U (2012) Evaluation of mosquitocidal activity of water extract of Moringa oleifera seeds against Culex quinquefasciatus (Diptera: Culicidae) in Pakistan. Pak Entomol 34(1):21-26

3. Benelli G, Jeffries CL, Walker T (2016) Biological control of mosquito vectors: past, present, and future. Insects 7(4):52

4. Borah R, Kalita M, Kar A, Talukdar A (2010) Larvicidal efficacy of Toddalia asiatica (Linn.) Lam against two mosquito vectors Aedes aegypti and Culex quinquefasciatus. African Journal of Biotechnology 9(17):2527-2530

5. Cetin H, Cinbilgel I, Yanikoglu A, Gokceoglu M (2006) Larvicidal activity of some Labiatae (Lamiaceae) plant extracts from Turkey. Phytotherapy Research: An International Journal Devoted to Pharmacological and Toxicological Evaluation of Natural Product Derivatives 20(12):1088-1090 
6. Cetin H, Erler F, Yanikoglu A (2004) Larvicidal activity of a botanical natural product, AkseBio2, against Culex pipiens. Fitoterapia 75(7):724-728

7. Coria C, et al. (2008) Larvicide and oviposition deterrent effects of fruit and leaf extracts from Melia azedarach on Aedes aegypti (L.)(Diptera: Culicidae). Bioresource Technology 99(8):3066-3070

8. Elango G, Rahuman AA, Bagavan A, Kamaraj C, Zahir AA, Venkatesan C (2009) Laboratory study on larvicidal activity of indigenous plant extracts against Anopheles subpictus and Culex tritaeniorhynchus. Parasitol Res 104(6):1381-1388

9. Elimam AM, Elmalik KH, Ali FS (2009) Larvicidal, adult emergence inhibition and oviposition deterrent effects of foliage extract from Ricinus communis against Anopheles arabiensis and Culex quinquefasciatus in Sudan. Trop Biomed 26(2):130-139

10. Finney D (1971) A statistical treatment of the sigmoid response curve. Probit analysis, 3rd edn Cambridge University Press, London 333

11. Govindarajan M, Mathivanan T, Elumalai K, Krishnappa K, Anandan A (2011a) Mosquito larvicidal, ovicidal, and repellent properties of botanical extracts against Anopheles stephensi, Aedes aegypti, and Culex quinquefasciatus (Diptera: Culicidae). Parasitology Research 109(2):353-367

12. Govindarajan M, Mathivanan T, Elumalai K, Krishnappa K, Anandan A (2011b) Ovicidal and repellent activities of botanical extracts against Culex quinquefasciatus, Aedes aegypti and Anopheles stephensi (Diptera: Culicidae). Asian Pacific Journal of Tropical Biomedicine 1(1):43-48

13. Guedes DR, et al. (2017) Zika virus replication in the mosquito Culex quinquefasciatus in Brazil. Emerging Microbes \& Infections 6(1):1-11

14. Guessan R, Corbel V, Akogbéto $M$, Rowland M (2007) Reduced efficacy of insecticide-treated nets and indoor residual spraying for malaria control in pyrethroid resistance area, Benin. Emerging Infect Dis 13(2):199

15. Hafeez F, Akram W, Shaalan EA-S (2011) Mosquito larvicidal activity of citrus limonoids against Aedes albopictus. Parasitol Res 109(1):221-229

16. Kilpatrick AM, Kramer LD, Jones MJ, Marra PP, Daszak P (2006) West Nile virus epidemics in North America are driven by shifts in mosquito feeding behavior. PLoS Biol 4(4):e82

17. Litchfield JT, Wilcoxon F (1949) A simplified method of evaluating dose-effect experiments. J Pharmacol Exp Ther 96(2):99-113

18. Lucantoni L, et al. (2006) Effects of a neem extract on blood feeding, oviposition and oocyte ultrastructure in Anopheles stephensi Liston (Diptera: Culicidae). Tissue and Cell 38(6):361-371

19. Mehra B, Hiradhar P (2002) Cuscuta hyalina Roth., an insect development inhibitor against common house mosquito Culex quinquefasciatus J Environ Biol 23(3):335-339

20. Mohan L, Sharma P, Srivastava C (2006) Evaluation of Solanum xanthocarpum extract as a synergist for cypermethrin against larvae of the filarial vector Culex quinquefasciatus (Say). Entomological Research 36(4):220-225 
21. Naumann K, Isman MB (1995) Evaluation of neem Azadirachta indica seed extracts and oils as oviposition deterrents to noctuid moths. Entomologia experimentalis et applicata 76(2):115-120

22. NJOM VS, UMEH EDN, EZE CS (2011) MALARIA VECTOR Anopheles gambiae. Animal Research International 8(2):1392-1397

23. Okumu FO, Moore SJ, Okumu F, Moore S (2011) Combining indoor residual spraying and insecticidetreated nets for malaria control in Africa: a review of possible outcomes and an outline of suggestions for the future. Malaria journal 10(208):1-13

24. Prathibha K, Raghavendra B, Vijayan V (2014) Larvicidal, ovicidal, and oviposition-deterrent activities of four plant extracts against three mosquito species. Environmental Science and Pollution Research 21(10):6736-6743

25. Rahuman AA, Gopalakrishnan G, Venkatesan P, Geetha K (2008) Larvicidal activity of some Euphorbiaceae plant extracts against Aedes aegypti and Culex quinquefasciatus (Diptera: Culicidae). Parasitol Res 102(5):867-873

26. Rajkumar S, Jebanesan A (2009) Larvicidal and oviposition activity of Cassia obtusifolia Linn (Family: Leguminosae) leaf extract against malarial vector, Anopheles stephensi Liston (Diptera: Culicidae). Parasitol Res 104(2):337-340

27. Robertson J, Preisler H (1992) Pesticide Bioassays with Arthropods. CRC, Boca Raton, FL

28. Rose RI (2001) Pesticides and public health: integrated methods of mosquito management. Emerging Infect Dis 7(1):17

29. Sangshetti JN, Shinde DB, Kulkarni A, Arote R (2017) Two decades of antifilarial drug discovery: a review. RSC advances 7(33):20628-20666

30. Shaalan EA-S, Canyon D, Younes MWF, Abdel-Wahab H, Mansour A-H (2005) A review of botanical phytochemicals with mosquitocidal potential. Environ Int 31(8):1149-1166

31. Shah RM, et al. (2017) Larval Habitat Substrates Could Affect the Biology and Vectorial Capacity of Culex quinquefasciatus (Diptera: Culicidae). J Med Entomol 54(3):638-645

32. Shahi M, Hanafi-Bojd A, Iranshahi M, Vatandoost H, Hanafi-Bojd M (2010) Larvicidal efficacy of latex and extract of Calotropis procera (Gentianales: Asclepiadaceae) against Culex quinquefasciatus and Anopheles stephensi (Diptera: Culicidae). J Vector Borne Dis 47(3):185-188

33. Simonsen PE, Mwakitalu ME (2013) Urban lymphatic filariasis. Parasitol Res 112(1):35-44

34. Singh R, Dhiman R, Mittal P (2007) Studies on mosquito larvicidal properties of Eucalyptus citriodora Hook (family-Myrtaceae). The Journal of Communicable Diseases 39(4):233-236

35. Tahir HM, Butt A, Khan SY (2009) Response of Culex quinquefasciatus to deltamethrin in Lahore district. J Parasitol Vector Biol 1(3):19-24

36. Tandon P, Sirohi A (2010) Assessment of larvicidal properties of aqueous extracts of four plants against Culex quinquefasciatus Jordan Journal of Biological Sciences 147(612):1-10

37. Tawatsin A, et al. (2006) Repellency of essential oils extracted from plants in Thailand against four mosquito vectors (Diptera: Culicidae) and oviposition deterrent effects against Aedes aegypti 
(Diptera: Culicidae). Southeast Asian J Trop Med Public Health 37(5):915-31

38. Van Bortel W, et al. (2008) The insecticide resistance status of malaria vectors in the Mekong region. Malaria journal 7(1):102

39. Wakil W, Ghazanfar M, Kwon Y, Ullah E, Islam S, Ali K (2014) Testing Paecilomyces lilacinus, diatomaceous earth and Azadirachta indica alone and in combination against cotton aphid (Aphis gossypii Glover)(Insecta: Homoptera: Aphididae). African Journal of Biotechnology 11(4):821-828

40. World Health Organization W (1996) Report of the WHO informal consultation on the evaluation and testing of insecticides, CTD/WHO PES/IC/ 1996; 96.1: 69.

\section{Tables}

Table 1. Lethal time ( $\left(\mathrm{LT}_{50}\right)$ values of the $24 \mathrm{~h}$ old larvae of Culex quinquefasciatus exposed to different botanicals 


\begin{tabular}{|c|c|c|c|c|c|c|}
\hline $\begin{array}{l}\text { Botanical } \\
\text { Extract }\end{array}$ & $\begin{array}{l}\text { Concentration } \\
\text { (PPM) }\end{array}$ & $\mathrm{LT}^{\mathrm{a} 1}{ }_{50}\left(95 \% \mathrm{Cl}^{\mathrm{b}}\right)$ & Slope ( $\pm S E)$ & $x 2^{c}$ & $D f^{d}$ & $P$ \\
\hline \multirow[t]{4}{*}{ Neem leaf } & 100 & $\begin{array}{l}184.312(137.69- \\
481.184)\end{array}$ & $0.017 \pm 0.006$ & 1.475 & 2 & 0.478 \\
\hline & 1000 & $\begin{array}{l}107.164(81.902- \\
1636.850)\end{array}$ & $0.022 \pm 0.003$ & 4.529 & 2 & 0.104 \\
\hline & 10000 & $\begin{array}{l}69.976(44.343- \\
120.657)\end{array}$ & $0.025 \pm 0.003$ & 5.902 & 2 & 0.052 \\
\hline & 100000 & $8.257(17.252-21.968)$ & $0.016 \pm 0.003$ & 0.089 & 2 & 0.956 \\
\hline \multirow[t]{4}{*}{ Neem Bark } & 100 & $A$ & $A$ & A & $A$ & $A$ \\
\hline & 1000 & $95.819(75.44-247.67)$ & $0.025 \pm 0.003$ & 4.658 & 2 & 0.097 \\
\hline & 10000 & $\begin{array}{l}66.338(61.365- \\
71.625)\end{array}$ & $0.027 \pm 0.003$ & 1.714 & 2 & 0.424 \\
\hline & 100000 & $28.52(20.468-34.481)$ & $0.029 \pm 0.003$ & 3.098 & 2 & 0.212 \\
\hline \multirow[t]{4}{*}{ Moringa leaf } & 100 & $\begin{array}{l}150.372(120.38- \\
715.81)\end{array}$ & $0.032 \pm 0.015$ & 0.13 & 2 & 0.937 \\
\hline & 1000 & $106.39(96.33-122.95)$ & $0.022 \pm 0.003$ & 1.867 & 2 & 0.393 \\
\hline & 10000 & $75.232(68.402-83.20)$ & $\begin{array}{l}0.020 \\
\pm 0.003\end{array}$ & 0.729 & 2 & 0.694 \\
\hline & 100000 & 11.16 (8.938-22.844) & $\begin{array}{l}0.019 \\
\pm 0.003\end{array}$ & 1.37 & 2 & 0.504 \\
\hline \multirow[t]{4}{*}{ Moringa Bark } & 100 & $A$ & $A$ & A & $A$ & $A$ \\
\hline & 1000 & 112.95(a) & $0.023 \pm 0.004$ & 4.847 & 2 & 0.089 \\
\hline & 10000 & $92.88(84.145-106.24)$ & $0.019 \pm 0.003$ & 3.791 & 2 & 0.15 \\
\hline & 100000 & $41.24(33.735-47.240)$ & $\begin{array}{l}0.024 \\
\pm 0.003\end{array}$ & 2.743 & 2 & 0.254 \\
\hline \multirow[t]{4}{*}{$\begin{array}{l}\text { Eucalyptus } \\
\text { Leaf }\end{array}$} & 100 & $\begin{array}{l}140.39(119.35- \\
198.78)\end{array}$ & $\begin{array}{l}0.024 \pm \\
0.006\end{array}$ & 1.289 & 2 & 0.525 \\
\hline & 1000 & $94.34(86.39-106.13)$ & $\begin{array}{l}0.022 \pm \\
0.003\end{array}$ & 3.604 & 2 & 0.165 \\
\hline & 10000 & $51.778(46.67-56.50)$ & $0.029 \pm 0.003$ & 2.360 & 2 & 0.307 \\
\hline & 100000 & $15.528(4.487-22.442)$ & $\begin{array}{l}0.036 \pm \\
0.005\end{array}$ & 0.528 & 2 & 0.768 \\
\hline \multirow[t]{2}{*}{$\begin{array}{l}\text { Eucalyptus } \\
\text { Bark }\end{array}$} & 100 & $191.880(a)$ & $\begin{array}{l}0.021 \pm \\
0.014\end{array}$ & 0.435 & 2 & 0.805 \\
\hline & 1000 & 94.343 (86.388- & 0.022 & 3.604 & 2 & 0.165 \\
\hline
\end{tabular}




\begin{tabular}{llllll|} 
& $106.128)$ & \pm 0.003 & & & \\
\hline 10000 & $\begin{array}{l}57.889(53.095- \\
62.572)\end{array}$ & $0.029 \pm$ & 2.02 & 2 & 0.364 \\
& $34.738(29.421-$ & $0.0037 \pm 0.004$ & 0.076 & 2 & 0.963 \\
\hline & $39.136)$ & & & & \\
\hline
\end{tabular}

"A/a"indicates that software was unable to calculate the value, "A/a"indicates that software was unable to calculate the value, a1=lethal time in hours, $\mathrm{Cl}=$ confidence intervals, $\mathrm{X}^{2}=$ chi-square goodness of fit test, $\mathrm{df}=$ degree of freedom

Table 2. Lethal time ( $\left(\mathrm{LT}_{50}\right)$ values of the $48 \mathrm{~h}$ old larvae of Culex quinquefasciatusa exposed to different botanicals 


\begin{tabular}{|c|c|c|c|c|c|c|}
\hline $\begin{array}{l}\text { Botanical } \\
\text { Extract }\end{array}$ & $\begin{array}{l}\text { Concentration } \\
\text { (PPM) }\end{array}$ & $\mathrm{LT}^{\mathrm{a} 1}{ }_{50}\left(95 \% \mathrm{Cl}^{\mathrm{b}}\right)$ & Slope $( \pm S E)$ & $x 2^{c}$ & $D f^{d}$ & $P$ \\
\hline \multirow[t]{4}{*}{ Neem leaf } & 100 & $545.688(a)$ & $0.005 \pm 0.006$ & 0.141 & 2 & 0.932 \\
\hline & 1000 & $\begin{array}{l}157.066(124.926- \\
360.985)\end{array}$ & $0.024 \pm 0.009$ & 1.234 & 2 & 0.539 \\
\hline & 10000 & $\begin{array}{l}71.049(64.155- \\
79.284)\end{array}$ & $0.019 \pm 0.003$ & 0.759 & 2 & 0.684 \\
\hline & 100000 & $\begin{array}{l}50.351(44.858- \\
55.319)\end{array}$ & $0.027 \pm 0.003$ & 0.419 & 2 & 0.811 \\
\hline \multirow[t]{4}{*}{ Neem Bark } & 100 & 191.888(a) & $0.021 \pm 0.014$ & 0.435 & 2 & 0.805 \\
\hline & 1000 & $169.160(a)$ & $0.025 \pm 0.014$ & 0.268 & 2 & 0.874 \\
\hline & 10000 & $\begin{array}{l}70.149(64.385- \\
76.722)\end{array}$ & $0.023 \pm 0.003$ & 0.251 & 2 & 0.882 \\
\hline & 100000 & $\begin{array}{l}54.006(49.271- \\
58.496)\end{array}$ & $0.031 \pm 0.003$ & 0.725 & 2 & 0.696 \\
\hline \multirow[t]{4}{*}{ Moringa leaf } & 100 & $123.14(a)$ & $\begin{array}{l}0.085 \\
\pm 0.372\end{array}$ & 0.001 & 2 & 0.999 \\
\hline & 1000 & $123.14(a)$ & $0.085 \pm 0.372$ & 0.001 & 2 & 0.999 \\
\hline & 10000 & $88.49(a)$ & $0.022 \pm 0.003$ & 8.512 & 2 & 0.014 \\
\hline & 100000 & $47.54(\mathrm{a})$ & $\begin{array}{l}0.020 \pm \\
0.003\end{array}$ & 9.935 & 2.000 & 0.007 \\
\hline \multirow[t]{4}{*}{ Moringa Bark } & 100 & $A$ & $A$ & A & $A$ & a \\
\hline & 1000 & $123.141(a)$ & $0.085 \pm 0.372$ & 0.001 & 2 & 0.999 \\
\hline & 10000 & $\begin{array}{l}115.256(88.925- \\
6217.97)\end{array}$ & $\begin{array}{l}0.023 \\
\pm 0.004\end{array}$ & 3.971 & 2 & 0.137 \\
\hline & 100000 & $\begin{array}{l}72.400(65.617- \\
80.624)\end{array}$ & $\begin{array}{l}0.019 \\
\pm 0.003\end{array}$ & 2.426 & 2 & 0.297 \\
\hline \multirow[t]{4}{*}{$\begin{array}{l}\text { Eucalyptus } \\
\text { Leaf }\end{array}$} & 100 & 285.803 (a) & $\begin{array}{l}0.011 \pm \\
0.008\end{array}$ & 0.653 & 2 & 0.721 \\
\hline & 1000 & $\begin{array}{l}207.524(142.97- \\
2516.20)\end{array}$ & $\begin{array}{l}0.015 \pm \\
0.007\end{array}$ & 0.405 & 2 & 0.817 \\
\hline & 10000 & $\begin{array}{l}63.864(57.784- \\
70.262)\end{array}$ & $\begin{array}{l}0.022 \pm \\
0.003\end{array}$ & 1.383 & 2 & 0.501 \\
\hline & 100000 & 47.915 (12.16-68.37) & $\begin{array}{l}0.030 \pm \\
0.003\end{array}$ & 6.1 & 2 & 0.047 \\
\hline $\begin{array}{l}\text { Eucalyptus } \\
\text { Bark }\end{array}$ & 100 & 191.88 (a) & $\begin{array}{l}0.021 \\
\pm 0.014\end{array}$ & 0.435 & 2 & 0.805 \\
\hline
\end{tabular}




\begin{tabular}{llllll|}
1000 & $339.974(\mathrm{a})$ & $0.007 \pm 0.005$ & .086 & 2 & 0.903 \\
\hline 10000 & $\begin{array}{l}69.56(63.327- \\
76.703)\end{array}$ & $0.021 \pm$ & 1.963 & 2 & 0.375 \\
& $\begin{array}{l}45.524(40.361- \\
100000\end{array}$ & $0.031 \pm 0$ & 0.292 & 2 & 0.864 \\
\hline
\end{tabular}

"A/a"indicates that software was unable to calculate the value, "A/a"indicates that software was unable to calculate the value, a1 $=\mathrm{a} 1=$ lethal time in hours, $\mathrm{Cl}=$ confidence intervals, $\mathrm{X}^{2}=$ chi-square goodness of fit test, $\mathrm{df}=$ degree of freedom

Table 3.Lethal time ( $\left(\mathrm{LT}_{50}\right)$ values of the $72 \mathrm{~h}$ old larvae of Culex quinquefasciatus exposed to different botanicals 


\begin{tabular}{|c|c|c|c|c|c|c|}
\hline $\begin{array}{l}\text { Botanical } \\
\text { Extract }\end{array}$ & $\begin{array}{l}\text { Concentration } \\
\text { (PPM) }\end{array}$ & $\mathrm{LT}^{\mathrm{a} 1}{ }_{50}\left(95 \% \mathrm{Cl}^{\mathrm{b}}\right)$ & Slope ( \pm SE) & $x 2^{c}$ & $D f^{d}$ & $P$ \\
\hline \multirow[t]{4}{*}{ Neem leaf } & 100 & $A$ & a & a & $A$ & a \\
\hline & 1000 & $A$ & a & a & $A$ & a \\
\hline & 10000 & $\begin{array}{l}136.869(116.511- \\
182.905)\end{array}$ & $0.018 \pm 0.004$ & 1.925 & 2 & 0.382 \\
\hline & 100000 & $\begin{array}{l}61.404(40.060- \\
83.379)\end{array}$ & $0.028 \pm 0.003$ & 4.761 & 2 & 0.093 \\
\hline \multirow[t]{4}{*}{ Neem Bark } & 100 & $A$ & a & a & $A$ & a \\
\hline & 1000 & $114.102(a)$ & $0.114 \pm 0.913$ & $<0.0001$ & 2 & 1 \\
\hline & 10000 & $131.090(a)$ & $0.021 \pm 0.004$ & 6.04 & 2 & 0.049 \\
\hline & 100000 & $\begin{array}{l}62.932(30.964- \\
99.006)\end{array}$ & $0.029 \pm 0.003$ & 7.476 & 2 & 0.024 \\
\hline \multirow[t]{4}{*}{ Moringa leaf } & 100 & $A$ & a & a & $A$ & a \\
\hline & 1000 & $A$ & a & a & $A$ & a \\
\hline & 10000 & 131.09 (a) & $\begin{array}{l}0.021 \pm \\
0.004\end{array}$ & 6.04 & 2 & 0.049 \\
\hline & 100000 & $56.106(a)$ & $\begin{array}{l}0.023 \pm \\
0.003\end{array}$ & 12.609 & 2 & 0.002 \\
\hline \multirow{4}{*}{$\begin{array}{l}\text { Moringa } \\
\text { Bark }\end{array}$} & 100 & $A$ & a & a & $A$ & a \\
\hline & 1000 & $A$ & a & a & $A$ & a \\
\hline & 10000 & $157.18(a)$ & $\begin{array}{l}0.014 \pm \\
0.004\end{array}$ & 7.024 & 2 & 0.03 \\
\hline & 100000 & $\begin{array}{l}80.014(72.948- \\
89.394)\end{array}$ & $\begin{array}{l}0.020 \pm \\
0.003\end{array}$ & 0.88 & 2 & 0.644 \\
\hline \multirow[t]{4}{*}{$\begin{array}{l}\text { Eucalyptus } \\
\text { Leaf }\end{array}$} & 100 & 123.141 (a) & $\begin{array}{l}0.085 \\
\pm 0.372\end{array}$ & 0.001 & 2 & 0.999 \\
\hline & 1000 & $\begin{array}{l}169.79(127.99- \\
981.16)\end{array}$ & $\begin{array}{l}0.023 \\
\pm 0.011\end{array}$ & 0.843 & 2 & 0.656 \\
\hline & 10000 & $\begin{array}{l}100.175(81.453- \\
210.426)\end{array}$ & $\begin{array}{l}0.027 \\
\pm 0.004\end{array}$ & 3.879 & 2 & 0.144 \\
\hline & 100000 & $\begin{array}{l}59.590(54.563- \\
64.613)\end{array}$ & $\begin{array}{l}0.027 \pm 0 \\
.003\end{array}$ & 1.427 & 2 & 0.49 \\
\hline \multirow{2}{*}{$\begin{array}{l}\text { Eucalyptus } \\
\text { Bark }\end{array}$} & 100 & $A$ & a & a & $A$ & a \\
\hline & 1000 & 123.141(a) & $\begin{array}{l}0.085 \pm 0 \\
.372\end{array}$ & 0.001 & 2 & 0.999 \\
\hline
\end{tabular}




\begin{tabular}{llllll|}
10000 & $102.028(92.181-$ & $0.020 \pm$ & 1.825 & 2 & 0.401 \\
& $117.970)$ & 0.003 & & & \\
\hline 100000 & $\begin{array}{l}62.136(56.978- \\
67.410)\end{array}$ & $0.026 \pm$ & 0.155 & 2 & 0.925 \\
\hline
\end{tabular}

"A/a"indicates that software was unable to calculate the value, a1=lethal time in hours, $\mathrm{Cl=confidence}$ intervals,

$\mathrm{X}^{2}=$ chi-square goodness of fit test, $\mathrm{df}=$ degree of freedom

Table 4. Correlation between lethal time $\left(\mathrm{LT}_{50}\right)$ values and different age groups of larvae of Culex quinquefasciatus exposed to highest tested concentration of different botanicals 


\begin{tabular}{|c|c|c|c|c|}
\hline $\begin{array}{l}\text { Botanical } \\
\text { Extracts }\end{array}$ & $\begin{array}{l}\text { Concentration } \\
\text { (PPM) }\end{array}$ & $\begin{array}{l}\text { Larval age } \\
\text { (h) }\end{array}$ & $\mathrm{LT}^{\mathrm{a} 1}{ }_{50}\left(95 \% \mathrm{Cl}^{\mathrm{b}}\right)$ & Correlation \\
\hline \multirow[t]{3}{*}{ Neem Leaf } & 100000 & 24 & $\begin{array}{l}8.257(17.252- \\
21.968)\end{array}$ & $\begin{array}{l}\left(r^{c}=0.95\right. \\
\left.P^{d}=0.21\right)\end{array}$ \\
\hline & & 48 & $\begin{array}{l}50.351(44.858- \\
55.319)\end{array}$ & \\
\hline & & 72 & $\begin{array}{l}61.404(40.060- \\
83.379)\end{array}$ & \\
\hline \multirow[t]{3}{*}{ Neem Bark } & 100000 & 24 & $\begin{array}{l}28.52(20.468- \\
34.481)\end{array}$ & $(\mathrm{r}=0.96, P=0.17)$ \\
\hline & & 48 & $\begin{array}{l}54.006(49.271- \\
58.496)\end{array}$ & \\
\hline & & 72 & $\begin{array}{l}62.932 \text { (30.964- } \\
99.006)\end{array}$ & \\
\hline \multirow[t]{3}{*}{ Moringa leaf } & 100000 & 24 & $11.16(8.938-22.844)$ & $(\mathrm{r}=0.94, P=0.22)$ \\
\hline & & 48 & $47.54(\mathrm{a})$ & \\
\hline & & 72 & $56.106(a)$ & \\
\hline \multirow[t]{3}{*}{ Moringa Bark } & 100000 & 24 & $41.24(33.735-47.240)$ & $(\mathrm{r}=0.94, P=0.21)$ \\
\hline & & 48 & $\begin{array}{l}72.400(65.617- \\
80.624)\end{array}$ & \\
\hline & & 72 & $\begin{array}{l}80.014(72.948- \\
89.394)\end{array}$ & \\
\hline \multirow[t]{3}{*}{ Eucalyptus Leaf } & 100000 & 24 & $15.528(4.487-22.442)$ & $(\mathrm{r}=0.97, P=0.17)$ \\
\hline & & 48 & 47.915 (12.16-68.37) & \\
\hline & & 72 & $\begin{array}{l}59.590(54.563- \\
64.613)\end{array}$ & \\
\hline \multirow[t]{3}{*}{ Eucalyptus Bark } & 100000 & 24 & $\begin{array}{l}34.738(29.421- \\
39.136)\end{array}$ & $(\mathrm{r}=0.99, P=0.08)$ \\
\hline & & 48 & $\begin{array}{l}45.524(40.361- \\
50.093)\end{array}$ & \\
\hline & & 72 & $\begin{array}{l}62.136(56.978- \\
67.410)\end{array}$ & \\
\hline
\end{tabular}

"a" indicate that software was unable to calculate the value, a1=lethal time in hours, $\mathrm{Cl}=$ confidence intervals,

$\mathrm{C}=$ coefficient of correlation, $P=$ Significance of correlation $(P>0.05)$ 
Figures

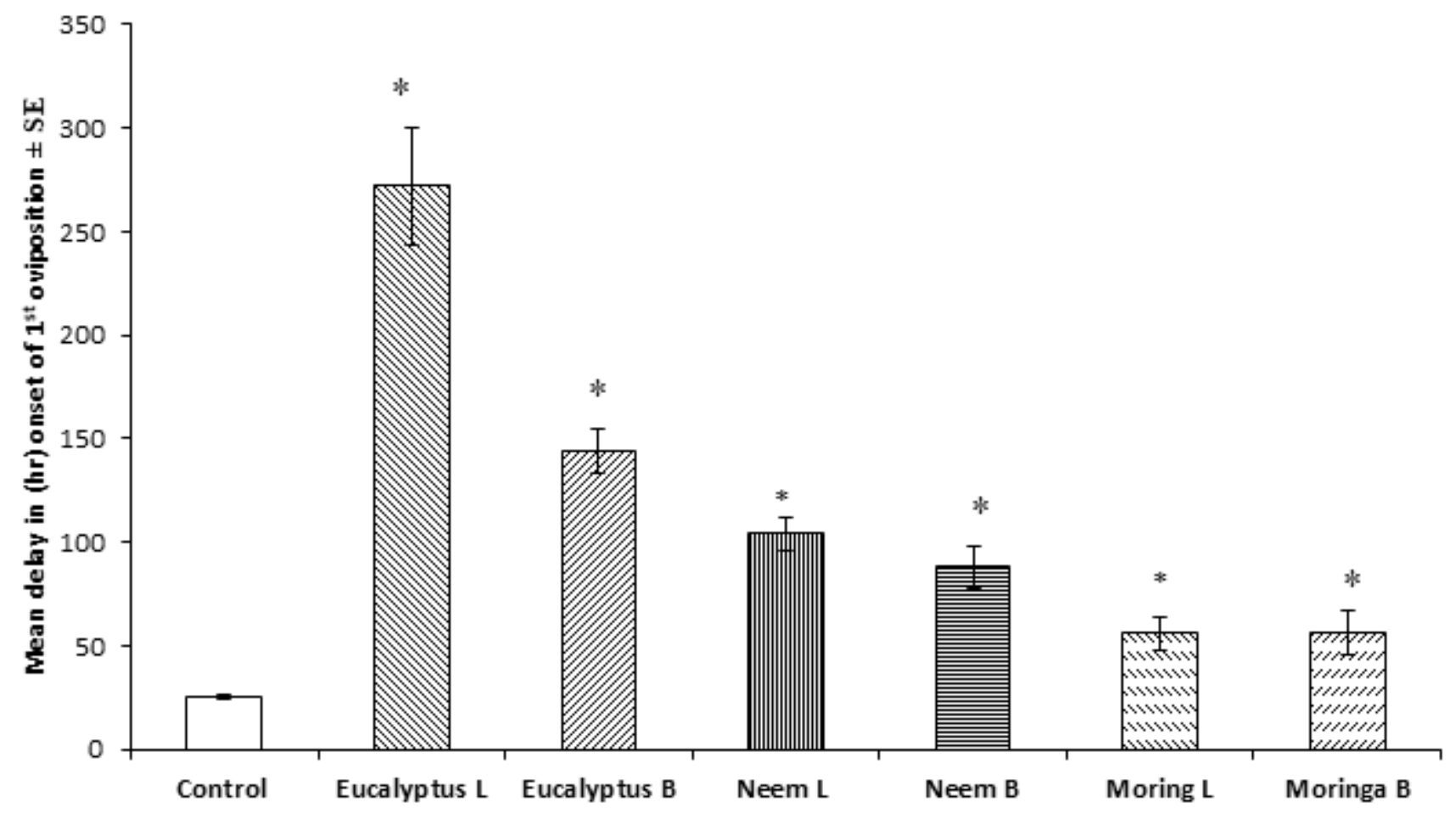

Figure 1

Effects of different plant water extracts in delaying 1 st oviposition in Culex quinquefasciatus. ${ }^{*}, * \star$ and $\star * \star$ indicate the significant delay in those treatments compared to the control at $P<0.05, P<0.005$ and, $P$ $<0.0001$ respectively. " $\mathrm{L}$ " and " $\mathrm{B}$ " denote leaf and bark, respectively. The error bars represent the standard error of the mean.

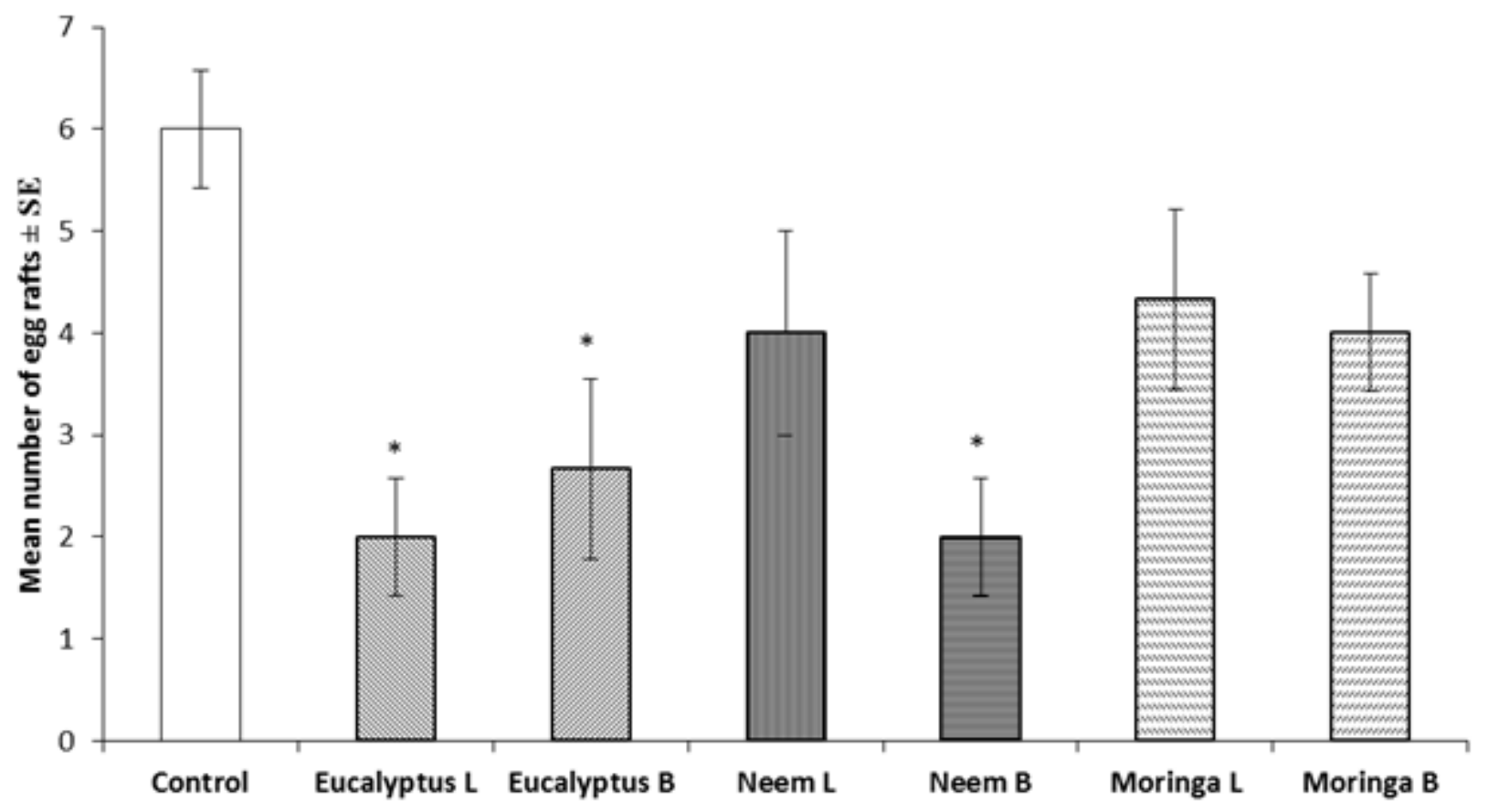


Figure 2

Effect of different botanicals on the production of egg rafts in Culex quinquefasciatus. ${ }^{*}, * \star$ and $* * *$ indicate the significant delay in those treatments compared to the control at $P<0.05, P<0.005$ and, $P$ $<0.0001$, respectively. The error bars represent the standard error of the mean.

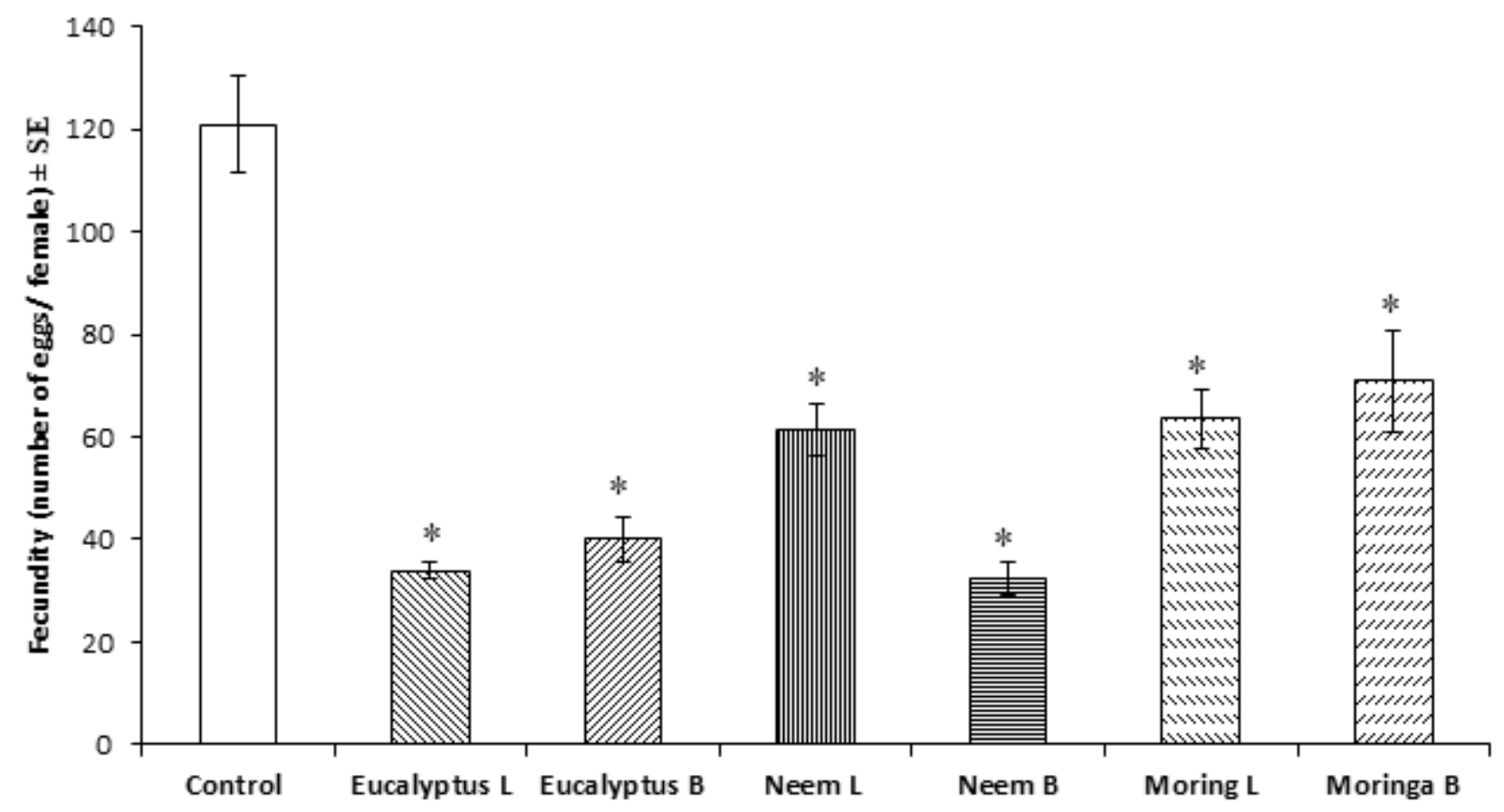

Figure 3

Effects of different plant water extracts on the fecundity of the Culex quinquefasciatus. * ${ }^{* \star}$ and $* \star \star$ indicate the significant delay in those treatments compared to the control at $P<0.05, P<0.005$ and, $P$ $<0.0001$ respectively. The error bars represent the standard error of the mean.

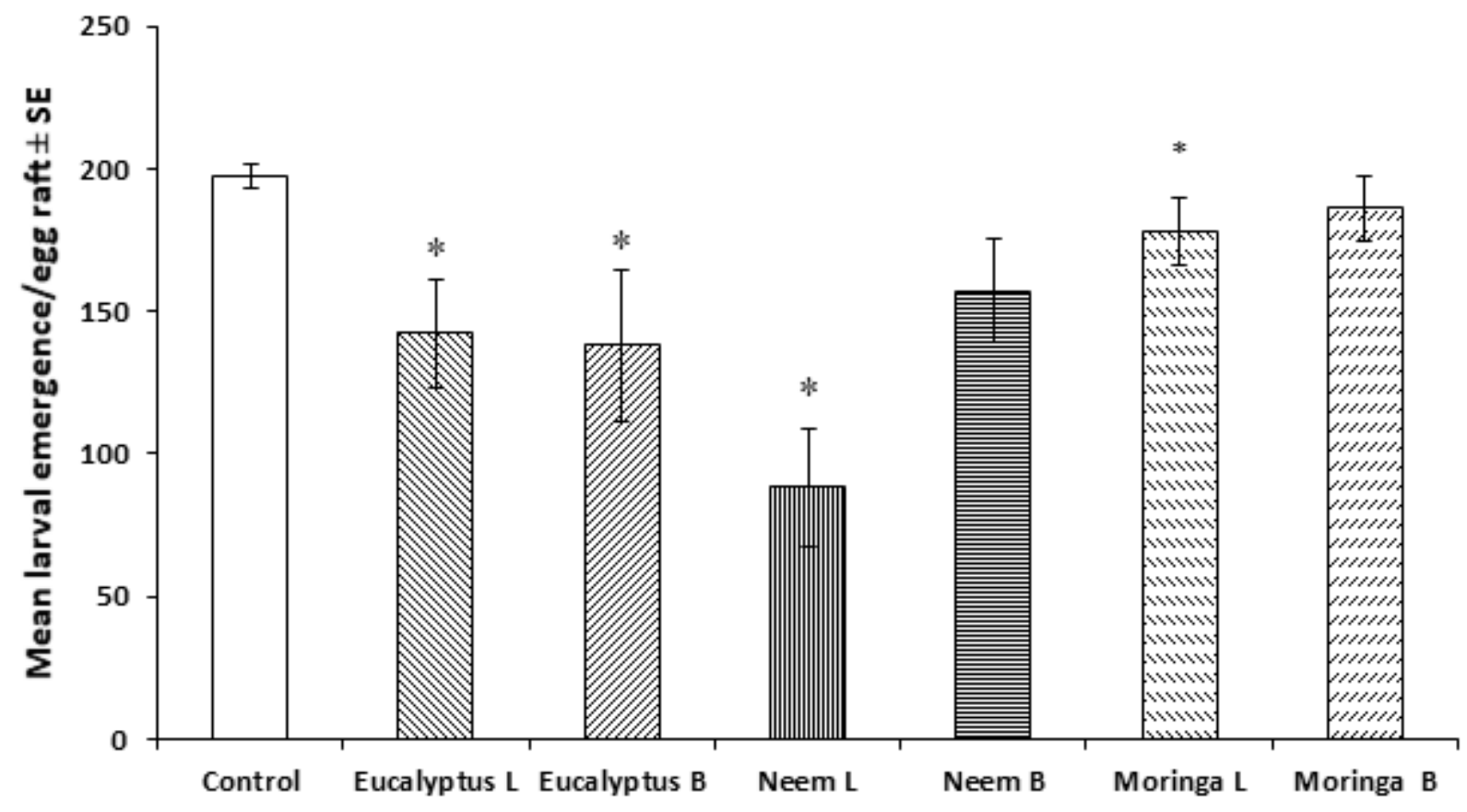


Figure 4

Effects of different plant water extracts on the larval emergence of the Culex quinquefasciatus. ${ }^{*}{ }^{*}$ and $\star \star \star$ indicate the significant delay in those treatments compared to the control at $P<0.05, P<0.005$ and, $P$ $<0.0001$, respectively. The error bars represent the standard error of the mean.

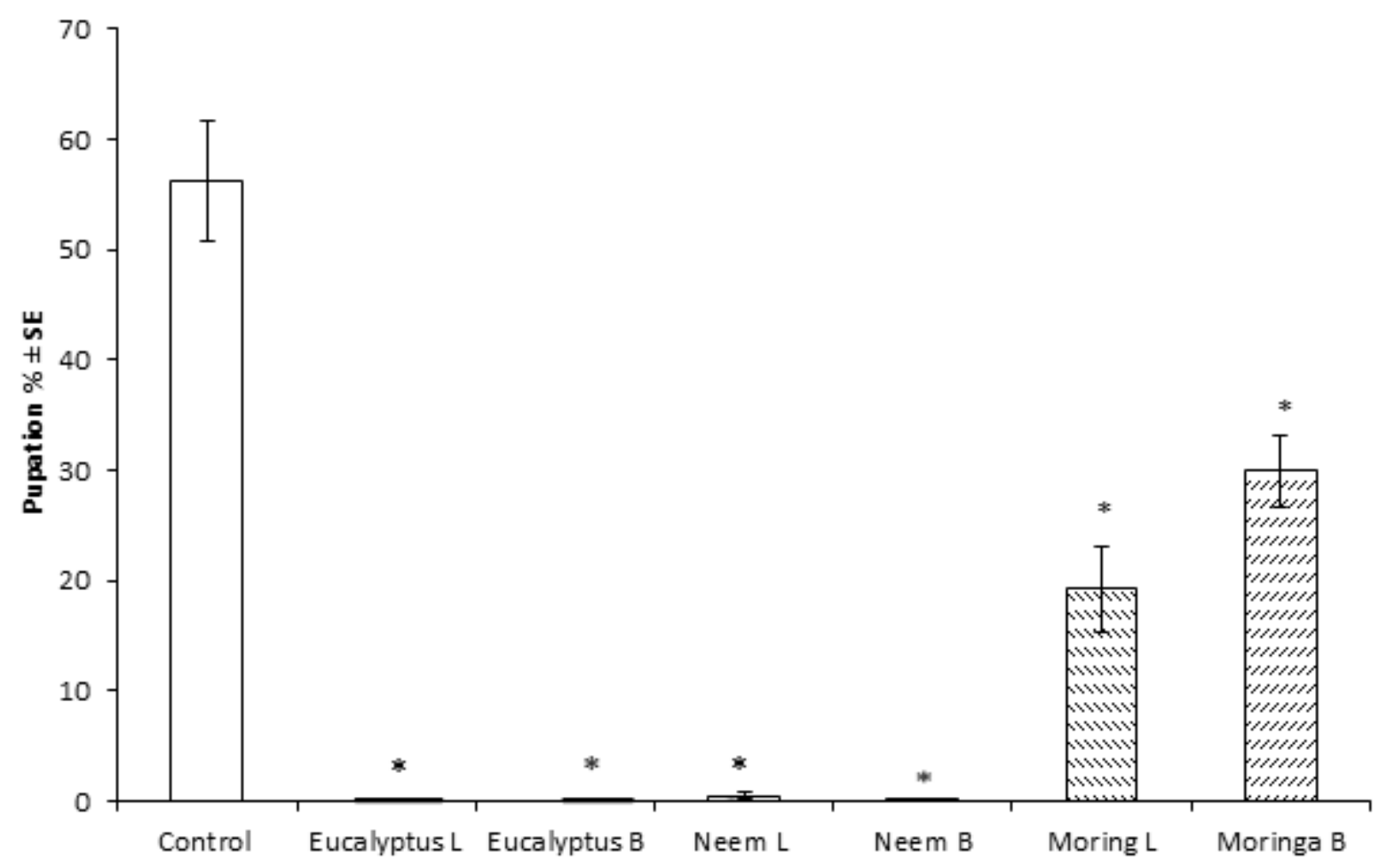

\section{Figure 5}

Effects of different plant water extracts on the pupation (\%) of the Culex quinquefasciatus. ${ }^{*}{ }^{*}$ and $* * *$ indicate the significant delay in those treatments compared to the control at $P<0.05, P<0.005$ and, $P$ $<0.0001$ respectively. The error bars represent the standard error of the mean. 


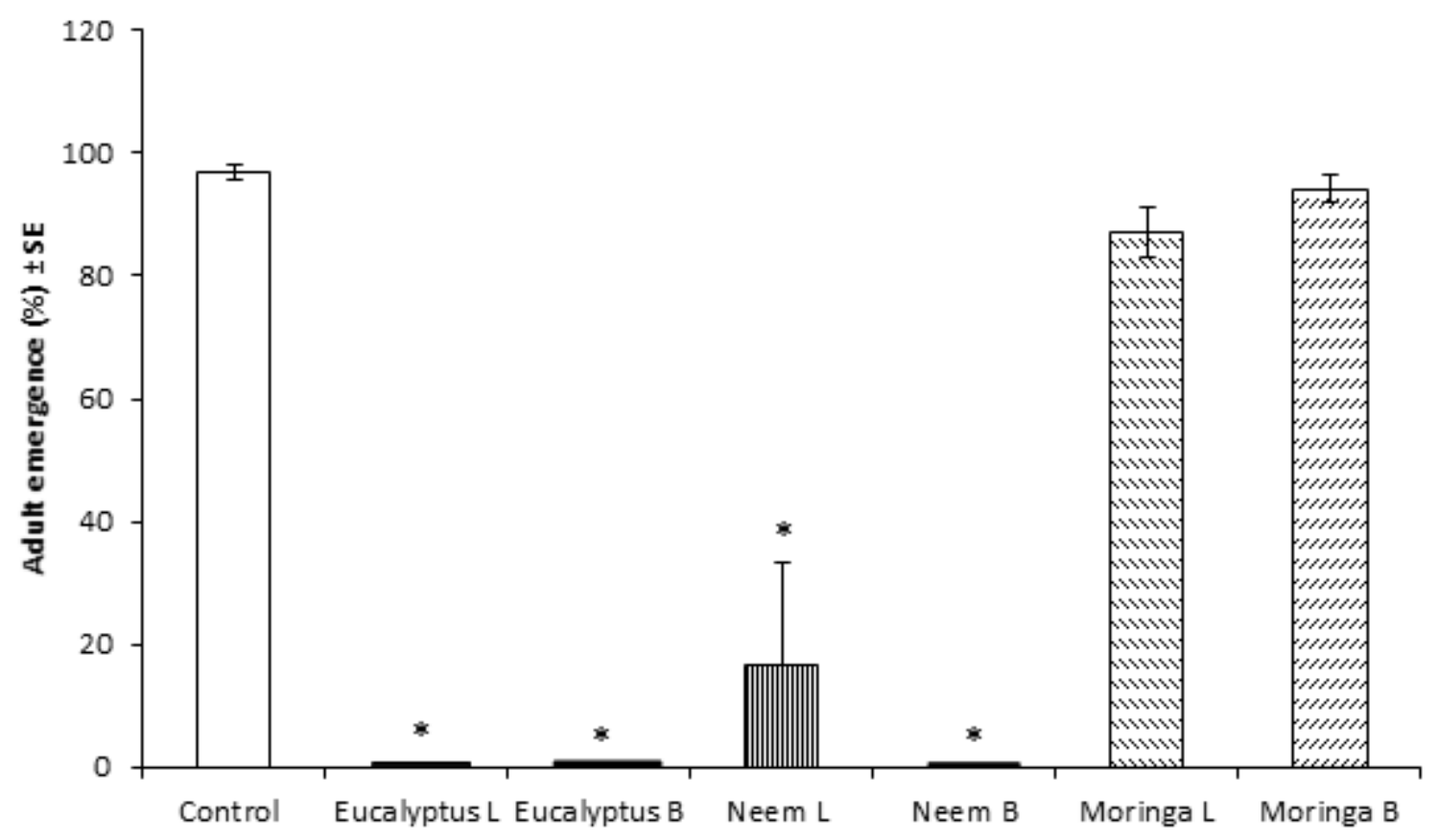

Figure 6

Effects of different plant water extracts on adult emergence of the Culex quinquefasciatus. ${ }^{*}, * \star$ and $* \star \star$ indicate the significant delay in those treatments compared to the control at $P<0.05, P<0.005$ and, $P$ $<0.0001$ respectively. The error bars represent the standard error of the mean. 